\title{
Interleukin-1, tumour necrosis factor and treatment of the septic shock syndrome
}

\author{
ChARLES A DinARELLO
}

\begin{abstract}
CA Dinarello. Interleukin-1, tumour necrosis factor and treatment of the septic shock syndrome. Can J Infect Dis 1992;3(Suppl B):11B-19B. Treating the septic shock syndrome with antibodies that block only endotoxin has its limitations. Other targets for treating septic shock include neutralizing antibodies to the complement fragment C5a, platelet activating factor antagonists and blockade of endothelial cell leukocyte adhesion molecules. Specific blockade of the pro-inflammatory cytokines interleukin-1 (IL-1) or tumour necrosis factor (TNF) reduces the morbidity and mortality associated with septic shock. Moreover, blocking IL-1 and TNF likely has uses in treating diseases other than septic shock. Use of neutralizing antibodies to TNF or IL-1 receptors has reduced the consequences of infection and inflammation, including lethal outcomes in animal models. The IL-1 receptor antagonist, a naturally occurring cytokine, blocks shock and death due to Escherichia coli as well as ameliorates a variety of inflammatory diseases. Soluble TNF and IL-1 surface receptors, which bind their respective cytokines, also ameliorate disease processes. Clinical trials are presently evaluating the safety and efficacy of anticytokine therapies either alone or in combination.
\end{abstract}

Key Words: Antagonists, Cytokines, Immunomodulators, Receptors

\section{L'interleukine-1, le facteur de nécrose tumorale, et le traitement du choc septique}

RÉSUMÉ: Le traitement du syndrome du choc septique qui consiste à administrer des anticorps qui ne bloquent que les endotoxines a ses limites. D'autres possibilités de traitement incluent les anticorps neutralisants du fragment C5a du complément, les antagonistes du facteur d'activation des plaquettes et le blocage des molécules d'adhérence des leucocytes aux cellules endothéliales. Le blocage spécifique de la cytokine pro-inflammatoire interleukine-1 (IL-1) ou du facteur de nécrose des tumorale (TNF) réduit la morbiditê et la mortalité associêes au choc septique. De plus, le blocage de l'IL-1 et du TNF peut probablement servir à traiter d'autres affections que le choc septique. Le recours aux anticorps neutralisants du TNF ou des récepteurs de l'IL-1 a rêduit les conséquences de l'infection et de l'inflammation, dont la létalité dans les modèles animaux. L'antagoniste du récepteur de l'IL-1, une cytokine sécrétée naturellement, bloque le choc et les décès causés par Escherichia coli et sert aussi à traiter une variêté de maladies inflammatoires. Le TNF soluble et les récepteurs de surface de l'IL-1, qui se lient à leurs cytokines respectives, améliorent aussi les processus pathologiques. Des essais cliniques évaluent présentement l'innocuité et l'efficacité des traitements par les anti-cytokines utilisées soit seules soit en association.

Department of Medicine, Tufts University and New England Medical Center, Boston, Massachusetts, USA

Correspondence and reprints: Dr Charles A Dinarello, New England Medical Center, 750 Washington Street, Boston, MA 02111, USA. Telephone (617) 956-7005, Fax (617) 956-5292 
Oryetr YTOKINES ARE SMALL PROTEINS WITH MOLECULAR WEIGHTS between 8000 and 30,000 Daltons. Each cytokine has a distinct amino acid sequence and cell surface receptors. They are produced by a variety of cell types and act on nearly every tissue and organ system. The names that have been given to the various cytokines have not followed a logical system but rather have been assigned according to biological property. For example, interleukin (IL)-1 and IL-2 were named 'interleukins' because, during the early years of cytokine research, both molecules were shown to activate lymphocytes. Today, as research on these molecules has greatly expanded, it has been recognized that the major effect of IL-2 is to activate lymphocytes, but the primary biological effect of IL-1 is the induction of fever, inflammation and hemodynamic shock. In fact, the biological effects of IL-1 are more closely related to the cytokine tumour necrosis factor (TNF). Although TNF does bring about necrosis in some tumours, its primary biological activities include endothelial cell activation, shock and death. IL-1 and TNF are the primary pro-inflammatory cytokines; moreover, these two cytokines act in a synergistic fashion in inducing inflammation, shock and death.

During infection, particularly bacterial infection, the genes for nearly all the cytokines are expressed. Some cytokines contribute to the demise of the host whereas others appear to be protective. One must be cautious with such a strict classification because whether a cytokine is harmful or beneficial to the host is dependent on the dose and time of administration. Nevertheless, the predominant biological effects of some cyto-

\section{TABLE}

\section{Properties of pro- and anti-inflammatory cytokines}

\section{Pro-inflammatory cytokines \\ Interleukin-1 (IL-1)/ \\ Tumour necrosis factor (TNF) \\ IL-8/NAP-1/MIP \\ Granulocyte macrophage colony stimulating factor (GM-CSF)

$$
\text { M-CSF }
$$

$\begin{array}{ll}\text { Anti-inflammatory cytokines } & \\ \text { Transforming growth } & \text { Blocks transcription of } \\ \text { factor-beta/IL-4/IL-6 } & \text { endotoxin-induced IL-1/TNF } \\ \text { IL-10 } & \text { Blocks production on IL-1/TNF } \\ \text { IL-1ra } & \text { Blocks binding of IL-1 }\end{array}$

kines, particularly when injected into humans, allow them to be grouped as being primarily pro- or anti-inflammatory molecules (Table 1).

IL- 1 and TNF share many pro-inflammatory properties and act synergistically. Combination of TNF and IL-1 can produce lethal shock in experimental animals. Part of the pro-inflammatory nature of IL-1 and TNF is through their ability to induce gene expression for other pro-inflammatory cytokines, most notably the family of neutrophil and monocyte chemotactic cytokines, namely IL-8, neutrophil activating protein-1, IL-9 and macrophage inflammatory proteins (MIP) (1). These cytokines stimulate neutrophil migration and degranulation in vivo. Granulocyte macrophage colony stimulating factor (GM-CSF) and macrophage CSF (M-CSF) are primarily bone marrow stimulants but they also activate neutrophils and macrophages, and induce TNF production, and hence can be considered to possess a pro-inflammatory component.

IL-4 and IL-6, which are primarily B cell stimulants, reduce endotoxin-induced $\mathrm{IL}-1$ and TNF production and hence can be considered anti-inflammatory. IL-6 is also an inducer of hepatic acute phase protein synthesis. Hepatic acute phase proteins bind lipids, bind several cytokines, are oxygen radical scavengers and possess anti-protease activity. Transforming growth factor-beta (TGF- $\beta$ ) is an immunosuppressive cytokine and a potent inhibitor of IL-1 and TNF gene expression. IL-10, a cytokine which structurally is related to Epstein-Barr virus protein, suppresses lymphocyte function but also reduces gene expression for IL-1. The IL- 1 receptor antagonist (IL-1 ra), which structurally is related to IL-1, blocks the activity of IL- 1 by occupying the IL-1 cell surface receptors but does not exhibit agonist activity.

\section{BIOLOGICAL PROPERTIES}

IL-1 was originally described as endogenous pyrogen (EP) (2); purified EP was very potent and produced fever at dosages of 25 to $50 \mathrm{ng} / \mathrm{kg}(3,4)$. EP did more than cause fever; it decreased plasma iron and zinc levels, produced neutrophilia, induced the appearance of a colony stimulating activity, and triggered the synthesis of hepatic amyloid A protein. It was subsequently demonstrated that EP augmented T lymphocyte responses to mitogens and hence 'lymphocyte activating factor' appeared to be another property of the EP molecule (5). The ability of a macrophage product to act as 'lymphocyte activating factor' resulted in the name interleukin.

Other substances originally described for their bio logical activities have been identified as IL-1. These are leukocytic endogenous mediator $(6,7)$, mononuclear cell factor (8), catabolin (9), osteoclast activating factor (10), hemopoietin-1 (11), lymphocyte proliferation promoting factor of neutrophils (12), melanoma growth inhibition factor (13) and tumour inhibitory factor-2 
(14). There are two structurally related forms of IL-1: IL- $1 \alpha$ and IL- $1 \beta$. There are also two structurally related forms of TNF: TNF $\alpha$ and TNF $\beta$. Each form of the respective cytokine recognizes the same cell surface receptors and triggers the same biological responses.

Considerable interest has focused on IL-1 and TNF as mediators of disease and in the production of systemic 'acute-phase' responses. A single injection of 10 to $100 \mathrm{ng} / \mathrm{kg}$ of either $\mathrm{IL}-1$ form into experimental animals results in fever, neutrophilia, increased circulating levels of colony stimulating factors, IL-6, hypozincemia, hypoferremia, increased hepatic acute-phase proteins synthesis, decreased albumin, anorexia, sleep, adrenocorticotropic hormone (ACTH) release and other manifestations of the response. At higher doses (5 $\mu \mathrm{g} / \mathrm{kg})$, IL-1 induces hypotension and leukopenia. Recent phase I clinical trials of IL-1 have confirmed the animal studies. The intravenous injection of 1 to 10 $\mathrm{ng} / \mathrm{kg}$ of either IL- $1 \alpha$ or IL- $1 \beta$ induces fever $(15,16)$. Higher doses of $100 \mathrm{ng}$ to $1 \mu \mathrm{g} / \mathrm{kg}$ have resulted in moderate to severe hypotension (16).

The intravenous injection of TNF into laboratory animals induces fever, leukopenia, increased circulating levels of colony stimulating factors, IL-6, hypozincemia, hypoferremia, increased hepatic acute-phase proteins synthesis, decreased albumin, anorexia, sleep, capillary leak, tissue damage, acidosis, hypotension and death. Although both IL-1 and TNF induce circulating CSFs, IL-1 appears to be a true bone marrow stimulant whereas TNF suppresses hematopoiesis. However, both IL-1 and TNF depress erythropoiesis.

The biological changes induced by the combination of these two cytokines are particularly impressive. Nearly all the responses to either IL-1 or TNF can be enhanced when the two cytokines are administered together. For example, TNF and IL-1 act synergistically in producing hemodynamic shock, leukopenia, lung hemorrhage and the 'acute respiratory distress syndrome'. The ability of IL-1 and TNF to induce the synthesis of endothelial adhesion molecules and the production of the neutrophil/monocyte chemotactic peptide family (IL-8/NAP-1 [neutrophil activating protein-1] MIP) likely plays a critical role in the pathogenesis of lung damage and inflammation due to neutrophils (17-19). IL-6, similar to IL-1 and TNF, causes fever and increases hepatic acute phase proteins synthesis, but unlike IL-1 and TNF, there does not seem to be a role for IL-6 in inducing inflammation or shock. Table 2 depicts the comparison between the biological activities of IL-1, TNF and IL-6.

There are no clear explanations for the synergistic action of IL- 1 and TNF. These two cytokines have their own distinct receptors. Although the precise nature of IL-1- or TNF-induced signal transduction remains controversial, the most consistent biological property of IL-1 and TNF in mediating disease appears to be the induction of or increase in gene expression for a unique
TABLE 2

Comparison of interleukin-1, tumour necrosis factor and interleukin-6

\begin{tabular}{lccc}
\hline Biological property & IL-1 & TNF & IL-6 \\
\hline Endogenous pyrogen fever & + & + & + \\
Slow wave sleep & + & + & - \\
Hepatic acute-phase proteins & + & + & + \\
T cell activation & + & + & + \\
B cell activation & + & + & + \\
B cell immunoglobin synthesis & - & - & + \\
Fibroblast proliferation & + & + & - \\
Stem cell activation (hemopoietin- 1 ) & + & - & + \\
Nonspecific resistance to infection & + & + & + \\
Radioprotection & + & + & - \\
Cyclooxygenase, PLA2 gene & & & \\
$\quad$ expression & + & + & - \\
Synovial cell activation & + & + & - \\
Endothelial cell activation & + & + & - \\
Shock syndrome & + & + & - \\
Induction of IL-1, TNF and IL-8 & + & + & - \\
Induction of IL-6 & + & + & - \\
\hline
\end{tabular}

IL Interleukin;TNF Tumour necrosis factor

constellation of proteins which mediate acute inflammation. IL-1 and TNF also suppress the expression of several 'household' proteins. It appears that there is an attempt to reduce the production of the cell's usual homeostasis proteins and shift its resources into the synthesis of proteins which enhance the ability to fight the invading organism. Whereas these responses to IL-1 and TNF are appropriate for the host to survive, there is a fine line between the beneficial aspect of this response and its cost to the host. Clearly, as the amount of IL-1 and TNF increase, the chances for a detrimental response increase. Opposing the action of detrimentals levels of IL-1 and TNF form the basis of using anticytokine strategies in treating the septic shock syndrome.

\section{IL-1 AND TNF-INDUCED GENE EXPRESSION}

IL- 1 and TNF induce the expression of a wide variety of genes, many of which code for cytokines. For example, IL-1 induces itself, IL-6 and TNF induce themselves as well as IL-1. The cytokine auto-induction cycle likely contributes to the synergistic effects of IL-1 and TNF. IL-1 and TNF induce the endothelial leukocyte adhesion molecules which play a major role in mediating the septic shock syndrome as well as several inflammatory diseases. In other situations IL-1 and TNF increase gene expression by stabilization and prolongation of mRNA half-life. IL-1 and TNF stimulate new transcripts for several proto-oncogenes. IL-1 and TNF suppress the transcription of constitutive genes, for example, albumin, cytochrome P450, lipoprotein lipase and aromatase. IL- 1 reduces the surface expression of its own type I receptor by accelerated mRNA degradation (20). IL-1 inhibits gene expression for thyroglobulin 


\begin{tabular}{l} 
TABLE 3 \\
Effects of interleukin-1 and tumour necrosis factor on \\
gene expression \\
\hline Genes increased \\
Interleukin (IL)-1, tumour necrosis factor, IL-6, interferon-beta-1 \\
IL-8, IL-9, macrophage inflammatory proteins \\
Granulocyte-macrophage (GM) colony stimulating factor \\
(CSF), G-CSF, M-CSF \\
Collagenases and stromelysin \\
Amyloid-A and -beta proteins \\
Metallothionein, ceruloplasmin \\
Complement (C), C2, factor B \\
Manganese superoxide dismutase \\
Cyclooxygenase, phospholipase A2 \\
Platelet-derived growth factor (AA) \\
Nerve growth factor \\
Adhesion molecules \\
Oncogenes (C-fos, C-myc, C-jun) \\
Tissue and urinary plasminogen activator \\
Plasminogen activator inhibitor \\
Corticotropin releasing factor \\
Pro-opiomelanocortin \\
Genes decreased \\
Albumin \\
Cytochrome P450 \\
Lipoprotein lipase \\
Aromatase \\
Aldosterone \\
Thyroglobulin \\
Preproinsulin \\
\hline
\end{tabular}

and thyroid peroxidase. In isolated rat adrenal glomerulosa cells stimulated with angiotensin-II, aldosterone biosynthesis is reduced by femtomolar concentrations of IL-1, probably by reduced mRNA transcripts. Table 3 summarizes the effect of IL-1 on gene expression.

\section{VASCULAR EFFECTS}

The systemic effects of high dosages (more than 1 $\mu \mathrm{g} / \mathrm{kg}$ ) of intravenous IL- 1 or TNF into animals includes hypotension, decreased systemic vascular resistance, depressed myocardial function, lactic acidosis, leukopenia, thrombocytopenia, vascular leak, pulmonary congestion and tissue neutrophilic infiltration with necrosis. The hypotensive effects of intravenously administered IL-1 in humans has been observed at dosages below $1 \mu \mathrm{g} / \mathrm{kg}$ and hypotension is the major clinical response for limiting the maximal dosage tolerated to $300 \mathrm{ng} / \mathrm{kg}$ (16). A nearly identical dose response for TNF in humans has been observed. The shock-like state which is observed in humans treated with high dose IL-2 likely is mediated via the intermediate production of IL-1 and TNF (21). The hypotensive effect of IL-1 and TNF may be via various mechanisms, one of which appears to result from cyclooxygenase products, and IL-1 and TNF act synergistically in increasing prostaglandin $\mathrm{E}$ (PGE) in a variety of cells. The hypotension following an IL-1/TNF injection into rabbits is blocked by cyclooxygenase inhibitors (18). Arterial perfusion with IL-1 increases prostanoid synthesis which lowers the pain threshold to bradykinin (22). TNF potentiates these effects of IL-1. IL-1 inhibits vascular smooth muscle contraction independently of prostaglandin synthesis. The inhibition of smooth muscle contraction by IL-1 appears to be due to an L-arginine-dependent increase in nitric oxide production leading to increased guanylate cyclase activity $(23,24)$.

Cultured endothelial cells exposed to IL-1 or TNF or a combination increase the expression of adhesion molecules which leads to the adherence of leukocytes to endothelial surfaces $(25,26)$. The mechanism for tissue neutrophil infiltration primarily is dependent on the induction of the adhesion molecules rather than activation of neutrophil. For example, tissue damage due to endotoxin can be reduced by passive immunization with antibodies which block the adhesion molecules.

IL-1 - and TNF-treated endothelial cells also increase procoagulant activity, tissue factor, $\mathrm{PGE}_{2}, \mathrm{PGI}_{2}$, platelet activating factor (PAF), plasminogen activator inhibitor production $(27,28)$, enhancement of thrombininduced von Willebrand's factor and synthesis of other cytokines including IL-1 (29). IL-1 and TNF also increase smooth muscle cell synthesis of themselves (30), other cytokines and platelet-derived growth factor (31). These effects of IL-1 and TNF are thought to play a role in the development of atherosclerosis and in vasculitis (32).

\section{IL-1 AND TNF PRODUCTION DURING DISEASE}

In humans with infections, endotoxemia, trauma, burns, acute bouts of rheumatoid arthritis, or undergoing organ transplant rejection, levels of IL-1 and TNF are elevated $(33,34)$. In patients with sepsis, the levels of TNF in the circulation increase proportionally with the degree of severity of hypotension and organ failure (33). However, circulating levels of IL-1 and TNF may be only transiently elevated and hence a single measurement may not reflect the amount of production of these cytokines. IL-6 levels are also elevated in these patients and correlate with the degree of disease severity. Measurement of IL-6 concentrations in the circulation can be a better indicator of the amount of IL-1 and TNF produced than measurement of the actual levels of IL-1 and TNF. In some experimental models, the amount of IL-6 appears to be under the control of IL-1 and TNF $(35,36)$.

In animal models of shock and Gram-negative sepsis, TNF levels rise rapidly after the injection of bacteria or endotoxin, reach peak levels at 60 to 90 mins and then decrease; IL-1 levels rise slowly and reach peak elevation at 180 mins. Similar kinetics have been observed in human subjects injected with endotoxin $(33,34)$. In rabbits, the amount of IL-1 and TNF which circulates correlates with the degree of hypotension (37). Furthermore, complement activation, induction of IL- 1 and TNF, shock and organ damage take place in the absence of endotoxemia (37). In fact, IL-1 and TNF 
are produced during Gram-positive sepsis, and plasma levels of these cytokines often correlate with the degree of hypotension even in the absence of staphylococcal exotoxins. These experiments support the concept that the production of IL-1 and TNF is the common denominator to the development of shock rather than the presence of lipopolysaccharide (LPS) endotoxins or various exotoxins. Thus, blocking IL-1 and TNF would be indicated therapeutically in shock due to Gram-negative, Gram-positive and fungal organisms as well as shock due to viral or parasitic infections.

\section{CONTROLLING THE SYNTHESIS OF IL-1 AND TNF}

Although the focus of anticytokine strategies in treating septic shock is specific for each cytokine, reducing the synthesis of either IL-1 or TNF, albeit nonspecific, reduces the biological responses to bacterial challenge or inflammation. A critical aspect of understanding IL-1 and TNF gene expression in a variety of cells is the exquisite sensitivity to endotoxins. This is particularly the case with human blood monocytes which synthesize IL-1 and TNF when stimulated by 10 to $20 \mathrm{pg} / \mathrm{mL}$ of endotoxin. In the strict absence of endotoxin, IL-1 and TNF gene expression occurs without translation into protein (38). Cells containing untranslated IL-1 or TNF mRNA are 'primed' and small amounts of other stimuli (endotoxin) rapidly trigger translation and usually result in more IL-1 and TNF synthesis than nonprimed cells. Another stimulus, heat-killed Staphylococcus epidermidis, primarily delivers a translational signal (38).

Blocking cyclooxygenase or histamine type-2 receptors can increase endotoxin-induced synthesis of IL-1 and TNF (particularly TNF) (39-42). Cyclooxygenase inhibitors and histamine type- 2 receptor antagonists block the negative signal of cytokine synthesis provided by prostaglandins and histamine. IL-1 and TNF transcription is suppressed by IL-4 (43), IL-6 (44), and TGF $\beta$ (45). The recently described cytokine IL-10, a product of T helper- 1 cells, suppresses the transcription of IL-4 and IL-5 (46), but also suppresses LPS-induced IL-1 synthesis. On the other hand, interferon- gamma (IFN $\gamma$ ) augments transcription and the amount of IL-1 synthesized following endotoxin or TNF stimulation (47, 48).

Corticosteroids suppress IL-1 transcription and synthesis when added before initiation of transcription but are less effective when added after transcription. Therefore, there is limited use of corticosteroids in blocking the synthesis of IL-1 and TNF once their genes are expressed. Agents that block the lipoxygenase pathway of arachidonate metabolism reduce IL-1 and TNF synthesis; however, this reduction is not via the 5-lipoxygenase pathway (49) but rather through 13-lipoxygenase (50). Dietary supplementation with eicosapentaenoic $(\omega-3)$ fatty acid resulted in a $70 \%$ reduction in ex vivo IL-1 and TNF synthesis $(51,52)$.
Anti-TNF antibodies: Neutralizing antibodies to murine or human TNF protect mice, rabbits and primates against death from endotoxemia or Escherichia coli sepsis, respectively (53-55). These experiments were the first to demonstrate that cytokine blockade was a potential strategy for the septic shock syndrome. The levels of IL-1 and IL-6 which circulate following the injection of $E$ coli into baboons is reduced markedly when animals are pretreated with anti-TNF antibodies (36) suggesting that TNF is providing a significant stimulus for IL-1 and IL- 6 synthesis. Antibodies to IL- 1 have not been tested in these models. However, neutralizing antibodies to the murine IL-1 receptor type I (IL-1RI) found on endothelial, hepatic and T cells block a variety of endotoxin and inflammation related responses such as protection from lethal radiation, anorexia and death $(35,56)$.

Naturally occurring inhibitors of IL-1 activity: Lipoproteins, lipids and $\alpha-2$ macroglobulin are examples of naturally occurring substances which inhibit IL-1 activity but these molecules also inhibit other cytokines, such as IL-6 and IL-2. There are polypeptides which specifically inhibit IL-1; these have been detected in the serum of humans injected with bacterial endotoxin (57), urine of febrile patients (58), plasma following hemodialysis (59), supernatants of human monocytes adhering to IgG coated surfaces (60) and urine of patients with monocytic leukemia (61). IL-1 specific inhibitory molecules of 52 to $66 \mathrm{kDa}$ secreted from a human myelomonocytic cell line (62) and the mouse macrophage cell line, P388D (63), have also been reported. The IL-1 receptor antagonist was originally called 'IL-1 inhibitor' $(61,64)$; it was a 23 to $25 \mathrm{kDa}$ protein purified from the urine of patients with monocytic leukemia $(61,64,65)$. Natural IL-1 inhibitor blocked the ability of IL- 1 to stimulate synovial cell $\mathrm{PGE}_{2}$ production, thymocyte proliferation and decreased insulin release from isolated pancreatic islets $(61,64,66,67)$. It is unclear whether similar IL-1-specific inhibitory activities found in serum during endotoxemia (57), in the urine of patients with fever (58) or secreted from myelomonocytic cell lines (62) share identity with the IL-1ra. IL-1 inhibitor blocked the binding of IL-1 to receptors on T cells and fibroblasts but did not affect the binding of TNF or IL-2 to their receptors $(64,67)$. IL- 1 inhibitor also did not bind to IL-1 itself unlike TNF inhibitors which were also isolated from the urine (68). Thus, IL-1 inhibitor was a competitive inhibitor of $\mathrm{IL}-1 / \mathrm{IL}-1$ receptor interaction.

Using IL-1 inhibitor purified from adherent monocytes $(60,69)$, the molecule was cloned $(70,71)$. The cDNA sequence codes for a polypeptide of approximately $17 \mathrm{kDa}$ with a $26 \%$ amino acid homology to IL- $1 \beta$ and a $19 \%$ homology to IL- $1 \alpha$. Conserved amino acids (72) revealed a $41 \%$ homology of $\mathrm{IL}-1$ ra to $\mathrm{IL}-1 \beta$ and $30 \%$ to IL- $1 \alpha$.

Similar to naturally occurring IL-1 urinary inhibitor (64), the recombinant IL-1 inhibitor competes with the 


\section{TABLE 4 \\ Reduction in severity of various disease models by specific cytokine antagonism}

\section{Anti-fumour necrosis factor (TNF) antibodies \\ Death in mice from endotoxin shock \\ Hemodynamic shock in baboons from Escherichia coli \\ Hemodynamic shock in rabbits from endotoxin}

\section{Soluble TNF receptors}

Death in mice from endotoxin shock

Interleukin (IL)-1 receptor antagonist

Death in mice and rabbits from endotoxin

Death in rabbits from $E$ coli

Hemodynamic shock in rabbits and baboons from E coli

Rat adjuvant arthritis

Inflammatory bowel disease in rabbits

Proliferation of acute myeloblastic leukemia cells

Proliferation of chronic myelogenous leukemia cells

\section{Anti-IL-1 receptor antibodies}

Anorexia in mice with turpentine inflammation Inflammation-induced amyloid P and IL-6 levels Lipopolysaccharide-induced radioprotection

\section{Soluble IL-1 receptor (type I)}

Rejection of heart allografts in mice

Lymph node swelling during rejection

binding of IL -1 to its cell surface receptors. Because of its sequence homology and mode of activity, IL-1 inhibitor was renamed 'IL-1 receptor antagonist' (IL-1ra). The IL-1ra blocks IL-1 activity in vitro and in vivo. In vitro, the IL-1 ra appears to occupy the IL-1RtI on T cells and fibroblasts with nearly the same affinity as that for bone fide IL-1 but without demonstrable agonist activity (69). Human IL-1 ra also blocks the binding of IL-1 to human cells bearing IL-1RtII such as neutrophils and B cells (73) as well as human peripheral myelomonocytic leukemia cells (74). Using murine $\mathrm{T}$ cells (IL-1RtI), human IL-1ra blocks the binding of IL-1 at nearly equimolar concentration; however, a 10- to 50fold molar excess of IL-1ra is required to block the binding of human IL-1 to human type II receptor bearing cells (73).

It is not surprising that recombinant IL-1ra will block the activity of IL-1 in various animal models of disease. Rabbits (75) or baboons (personal communication) injected with IL-1 develop hypotension which is reversed by prior administration of the IL-1ra. However, a larger question remains: during acute or chronic disease several cytokines are produced but what is the effect of specific blockade of IL-1?

\section{EFFECT OF IL- 1 ra ON SEPTIC SHOCK}

The administration of IL-1ra prevents death in rabbits from LPS shock (75). Intravenous injection of $E$ coli to rabbits produces several manifestations of the septic shock syndrome, namely hypotension, decreased systemic vascular resistance, leukopenia, thrombocytopenia and tissue damage. When rabbits were pretreated with the IL-lra, only a transient and mild hypotensive epi- sode was observed whereas severe and sustained hypotension with a $50 \%$ mortality was observed in control rabbits (76). There were also reduced numbers of tissue-infiltrating neutrophils. In these studies the circulating levels of TNF and IL-1 $\beta$ were unchanged. The interpretation of these results suggests that TNF may be responsible for the initial fall in blood pressure but that IL- 1 is playing an essential role in the progression of the shock state. Human IL-lra also prevents lethal Klebsiella pneumoniae sepsis in newborn rats (77) and $E$ coli-induced hypotension in baboons (personal communication).

Other effects of the $\mathrm{IL}$-1ra: Data support a role for IL-1 in the pathogenesis of colitis; rabbits injected with soluble immune complexes develop tissue inflammatory cell infiltration, edema and necrosis of the lower colon. However, when treated with the IL-1ra, a marked decrease in infiltrating neutrophils was observed (78). In addition, decreased $\mathrm{PGE}_{2}$ was measured in the rectal lumen despite the fact that IL-1 tissue levels were unchanged (79). Together, these data demonstrate that blockade of IL-1 prevents the onset and development of the inflammatory lesion in this model of immune complex-induced colitis.

An autocrine role for IL-1 has been proposed in leukemia in which IL-1 production by leukemic blasts is uncontrolled and results in production of CSFs. The CSFs, in turn, drive proliferation of the cells. Antibodies to human IL-1 $\beta$ reduce the spontaneous proliferation and colony stimulating activity production of juveniletype chronic granulocytic (80) and acute myelogenous leukemia cells (81). Recent studies have shown that IL-1ra blocks the spontaneous proliferation as well as spontaneous production of GM-CSF, IL-1 and IL-6 in peripheral blood- or bone marrow-derived acute myelogenous leukemia cells from over 25 patients (74). When IL-1 ra was removed after a $48 \mathrm{~h}$ exposure, the leukemic cells showed evidence of death during a subsequent 72 $\mathrm{h}$ incubation.

IL-1ra blocks IL-1-induced thymocyte proliferation as well as IL-1-induced synovial cell $\mathrm{PGE}_{2}$ synthesis and collagenase synthesis from chondrocytes (82). A 100-fold molar excess of IL-1ra to IL-1 is required (82). IL-ra also blocks the production of IL-1-induced IL-1, TNF and IL-6 from human peripheral blood mononuclear cells (PBMC) as well as from purified monocytes (83). In a rabbit model of meningeal inflammation, IL-1ra blocked cerebrospinal pleocytosis induced by cerebroventricular IL-1 (84); this required a 5000-fold molar excess of IL-1 ra to block $90 \%$ of the IL-1-induced pleocytosis. A similar study has shown that intracerebroventricular injection of $100 \mu \mathrm{g}$ of the IL-1ra $(10,000-$ fold excess) blocks nonrapid eye movement sleep and fever induced by $10 \mathrm{ng}$ of IL- $1 \beta$ given by the same route (85). Systemic injection of the 100-fold molar excess of the IL-lra blocks $95 \%$ of the fever due to the intravenous injection of IL-1 in rabbits (86). Administration of IL-1ra 
to rats with adjuvant arthritis has reduced the severity of the joint lesions.

\section{SOLUBLE IL- IR AND TNF PROTEINS}

The extracellular domain of IL-1RtI has been expressed and shown to bind both forms of IL-1. Unlike soluble TNF, IL-6 and INF $\gamma$ receptors which occur naturally in the urine $(68,87)$, soluble IL- 1 receptors have yet to be found naturally. Nevertheless, when recombinant soluble IL-1RtI was given to rats undergoing heart allograft rejection, survival of the heterotopic grafts was increased. Lymph nodes directly injected with allogeneic cells have reduced hyperplasia with the use of soluble IL-1RtI (88). It is likely that the effects of the soluble type I receptor is due to decreased inflammation rather than decreased immunoresponsiveness. Although there are no data suggesting that the type I

ACKNOWLEDGEMENTS: These studies are supported by NIH grant AI 15614.

\section{REFERENCES}

1. Oppenheim JJ, Matsushima K, Yoshimura T, Leonard EJ, Neta R. Relationship between interleukin 1 (ILl), tumor necrosis factor (TNF) and a neutrophil attracting peptide (NAP-1). Agents Actions 1989;26:134-40.

2. Atkins E. Pathogenesis of fever. Physiol Rev 1960;40:580-646.

3. Dinarello CA, Renfer L, Wolff SM. Human leukocytic pyrogen: Purification and development of a radioimmunoassay. Proc Natl Acad Sci USA 1977;74:4624-7.

4. Murphy PA, Chesney PJ, Wood WB Jr. Further purification of rabbit leukocyte pyrogen. J Lab Clin Med 1974;83:310-22.

5. Dinarello CA, Cannon JG, Wolff SM. New concepts on the pathogenesis of fever. Rev Infect Dis 1988;10:168-89.

6. Kampschmidt RF. Leukocytic endogenous mediator/endogenous pyrogen. In: Powanda MC, Canonico PG, eds. Physiologic and Metabolic Responses of the Host. Amsterdam: Elsevier, 1981:55-74.

7. Merriman CR, Pulliam LA, Kampschmidt RF. Comparison of leukocytic pyrogen and leukocytic endogenous mediator. Proc Soc Exp Biol Med 1977;154:224-7.

8. Krane SM, Conca W, Stephenson ML, Amento EP, Goldring MB. Mechanisms of matrix degradation in rheumatoid arthritis. Ann NY Acad Sci 1990;580:340-54.

9. Saklatvala J, Sarsfield SJ, Townsend Y. Pig interleukin 1: Purification of two immunologically different leukocyte proteins that cause cartilage resorption, lymphocyte activation, and fever. J Exp Med 1985;162:1208-22.

10. Dewhirst FE, Stashenko PP, Mole JE, Tsurumachi T. Purification and partial sequence of human osteoclastactivating factor: Identity with interleukin 1 beta. J Immunol 1985; 135:2562-8.

11. Moore MA, Warren DJ. Synergy of interleukin 1 and granulocyte colony-stimulating factor: In vivo stimulation of stem-cell recovery and hematopoietic regeneration following 5-fluorouracil treatment of mice. Proc Natl Acad Sci USA 1987;84:7134-8.

12. Mori S, Goto F, Goto K, et al. Cloning and sequence analysis of a cDNA for lymphocyte proliferation potentialing factor of rabbit neutrophils: Identification as
IL-1 receptor is naturally shed, conditioned media from IL-1RtII-bearing Raji cells contain the soluble form (35 to $45 \mathrm{kDa}$ ) of IL-IRtII (89).

Similar to IL-1, there are two cell surface receptors for TNF, but unlike IL-1 receptors, soluble TNF receptors are found naturally in the urine of normal humans. The soluble TNF receptors were initially described as specific TNF binding proteins and later shown to represent the shed forms of the extracellular segments of TNF receptors (68). Soluble TNF receptors bind TNF with affinities equal to those of the intact receptors found on cells and render TNF incapable of agonist activity. The use of soluble TNF receptors holds promise in the treatment of septic shock and other disease states where TNF plays a pathological role. Table 4 lists the effects of specific cytokine antagonists on the severity of disease in various animal models.

rabbit interleukin-1 $\beta$. Biochem Biophys Res Comm 1988; 150:1237-43.

13. Nishida T, Nishino N, Takano M, et al. cDNA cloning of IL-1 alpha and IL- 1 beta from mRNA of U937 cell line. Biochem Biophys Res Commun 1987;143:345-52.

14. Fryling C, Dombalagian M, Burgess W, Hollander N, Schreiber BB, Heimovich J. Purification and characterization of tumor inhibitory factor-2: Its identity to interleukin-1. Cancer Res 1989;49:3333-7.

15. Tewari A, Buhles WC Jr, Starnes HF Jr. Preliminary report: Effects of interleukin-1 on platelet counts. Lancet 1990;336:712-4.

16. Smith J, Urba W, Steis R, et al. Interleukin-1 alpha: Results of a phase I toxicity and immunomodulatory trial. Am Soc Clin Oncol 1990;9:717.

17. Goldblum SE, Cohen DA, Gillespie MN, McClain CJ. Interleukin 1-induced granulocytopenia and pulmonary leukostasis in rabbits. J Appl Physiol 1987;62:122-8.

18. Okusawa S, Gelfand JA, Ikejima T, Connolly RJ, Dinarello CA. Interleukin 1 induces a shock-like state in rabbits. Synergism with tumour necrosis factor and the effect of cyclooxygenase inhibition. J Clin Invest 1988;81:1162-72.

19. Tredget EE, Yu YM, Zhong S, et al. Role of interleukin 1 and tumor necrosis factor on energy metabolism in rabbits. Am J Physiol 1988;255:E760-8.

20. Ye K, Clark BD, Dinarello CA. Interleukin-1 $\beta$ downregulates gene and surface expression of interleukin-1 receptor type I by destabilizing its mRNA whereas interleukin-2 increases its expression. Clin Res 1992;75:427-34.

21. Mier JW, Vachino G, van der Meer JW, et al. Induction of circulating tumor necrosis factor (TNF alpha) as the mechanism for the febrile response to interleukin-2 (IL-2) in cancer patients. J Clin Immunol 1988;8:426-36.

22. Schweizer A, Feige U, Fontana A, Muller K, Dinarello CA. Interleukin-1 enhances pain reflexes. Mediation through increased prostaglandin E2 levels. Agents Actions 1988;25:246-51.

23. Beasley D, Schwartz JH, Brenner BM. Interleukin-1 induces prolonged $\mathrm{L}$-arginine-dependent cyclic guanosine monophosphate and nitrite production in rat vascular smooth muscle cells. J Clin Invest 1991;87:602-8.

24. Beasley D. Interleukin 1 and endotoxin activate soluble guanylate cyclase in vascular smooth muscle. Am J Physiol 1990. 
25. Pohlman TH. An endothelial cell surface factor(s) induced in vitro by lipopolysaccharide, interleukin-1, and tumor necrosis factor increases neutrophil by a CDw18dependent mechanism. J Immunol 1986;136:4548-53.

26. Bevilacqua MP, Pober MS, Wheeler ME, Cotran RS, Gibrone MA Jr. Interleukin 1 acts on cultured human vascular endothelium to increase the adhesion of polymorphonuclear leukocytes, monocytes and related leukocyte cell lines. J Clin Invest 1985;76:2003-11.

27. Dejana E, Breviario F, Erroi A, et al. Modulation of endothelial cell functions by different molecular species of interleukin 1. Blood 1987;69:695-9.

28. Rossi V, Breviario F, Ghezzi P, Dejana E, Mantovani A. Prostacyclin synthesis induced in vascular cells by interleukin-1. Science 1985;229:174-6.

29. Libby P, Ordovas JM, Birinyi LK, Auger KR, Dinarello CA. Inducible interleukin-1 gene expression in human vascular smooth muscle cells. J Clin Invest 1986;78:1432-8.

30. Warner SJC, Auger KR, Libby P. Human interleukin 1 induces interleukin 1 gene expression in human vascular smooth muscle cells. J Exp Med 1987;165:1316-31.

31. Raines EW, Dower SK, Ross R. Interleukin-1 mitogenic activity for fibroblasts and smooth muscle cells is due to PDGF-AA. Science 1989;243:393-6.

32. Movat HZ, Burrowes CE, Cybulsky MI, Dinarello CA. Acute inflammation and a Shwartzman-like reaction induced by interleukin-1 and tumor necrosis factor. Synergistic action of the cytokines in the induction of inflammation and microvascular injury. Am J Pathol 1988; 130:642.

33. Cannon JG, Tompkins RG, Gelfand JA, et al. Circulating interleukin-1 and tumor necrosis factor in septic shock and experimental endotoxin fever. $J$ Inf Dis 1990; 161:79-84.

34. Michie HR, Manogue KR, Spriggs DR, et al. Detection of circulating tumor necrosis factor after endotoxin administration. N Engl J Med 1988;318:1481-6.

35. Gershenwald JE, Fong YM, Fahey TJ, et al. Interleukin 1 receptor blockade attenuates the host inflammatory response. Proc Natl Acad Sci USA 1990;87:4966-70.

36. Fong Y, Tracey KJ, Moldawer LL, et al. Antibodies to cachectin/tumor necrosis factor reduce interleukin $1 \beta$ and interleukin 6 appearance during lethal bacteremia. J Exp Med 1989;170:1627-33.

37. Wakabayashi G, Gelfand JA, Jung WK, Connolly RJ, Burke JF, Dinarello CA. Staphylococcus epidermidis induces complement activation, TNF, IL-1, a shock-like state and tissue injury in rabbits without endotoxemia: Comparison to Escherichia coli. J Clin Invest 1991;87:1925-55.

38. Schindler R, Clark BD, Dinarello CA. Dissociation between interleukin-1 $\beta$ mRNA and proteiñ synthesis in human peripheral blood mononuclear cells. J Biol Chem 1990;265:10232-7

39. Knudsen PJ, Dinarello CA, Strom TB. Prostaglandins post transcriptionally inhibit monocyte expression of interleukin 1 activity by increasing intracellular cyclic adenosine monophosphate. J Immunol 1986; 137:3189-94.

40. Hurme M. Modulation of interleukin- $1 \beta$ production by cyclic AMP in human monocytes. FEBs Lett 1990;263:35-7.

41. Vannier E, Miller LC, Schindler R, Terlain B, Dinarello CA. Histamine suppresses the synthesis of tumor necrosis factor- $\alpha$ in vitro via $\mathrm{H}_{2}$ receptors. Cytokine 1989;1:123. (Abst)

42. Endres S, Fuelle H-J, Sinha B, et al. Cyclic nucleotides differentially regulate the synthesis of tumour necrosis factor- $\alpha$ and interleukin-1 $\beta$ by human mononuclear cells. Immunol 1991;72:56-60.

43. Hart PH, Vitti GF, Burgess DR, Whitty GA, Piccoh DS, Hamilton JA. Potential anti-inflammatory effects of interleukin-4: Suppression of human monocyte tumor necrosis factor, interleukin-1 and prostaglandin E2. Proc Natl Acad Sci USA 1989;86:3803-7.

44. Schindler R, Mancilla J, Endres S, Ghorbani R, Clark SC, Dinarello CA. Correlations and interactions in the production of interleukin-6 (IL-6), IL-1, and tumor necrosis factor (TNF) in human blood mononuclear cells: IL-6 suppresses IL-1 and TNF. Blood 1990;75:40-7.

45. Chantry D, Turner M, Abney E, Feldmann M. Modulation of cytokine production by transforming growth factorbeta. J Immunol 1989; 142:4295-300.

46. Moore KW, Vieira P, Fiorentino DF, Trounstine AM, Khan TA, Mosmann TR. Homology of cytokine synthesis inhibitory factor (IL-10) to the Epstein-Barr virus gene BCRFI. Science 1990;248:1230-4.

47. Schindler R, Ghezzi P, Dinarello CA. IL-1 induces IL-1. IV. IFN $\gamma$ suppresses IL-1 but not lipopolysaccharideinduced transcription of IL-1. J Immunol 1990; 144:2216-22.

48. Ucla C, Roux-Lombard P, Fey S, Dayer J-M, Mach B. Interferon gamma drastically modifies the regulation of interleukin 1 genes by endotoxin in U937 cells. J Clin Invest 1990;85:185-91.

49. Sirko S, Schindler R, Doyle MJ, Weisman SM, Dinarello CA. Transcription, translation and secretion of IL- 1 and TNF: Effect of tebufelone a dual cyclooxygenase and lipoxygenase inhibitor. Eur J Immunol 1991;21:243-50.

50. Schade UF, Burmeister I, Engel R. Increased 13-hydroxyoctadecadienoic acid content in lipopolysacharide stimulated macrophages. Biochem Biophys Res Comm 1987; 147:695-700.

51. Endres S, Ghorbani R, Kelley VE, et al. The effect of dietary supplementation with n-3 polyunsaturated fatty acids on the synthesis of interleukin-1 and tumor necrosis factor by mononuclear cells. N Engl $\mathrm{J}$ Med 1989;320:265-71.

52. Meydani SN, Endres S, Woods MM, et al. Oral N-3 fatty acid supplmentation suppresses cytokine production and lymphocyte prolieration: Comparison in young and older women. J Nutr 1991;121:547-55.

53. Tracey K, Fong Y, Hesse DG, et al. Anti-cachectin/TNF monoclonal antibodies prevent septic shock during lethal bacteremia. Nature 1987;330:662-4.

54. Beutler B, Milsark IW, Cerami A. Passive immunization against cachetin/tumor necrosis factor protects mice from lethal effect of endotoxin. Science 1985;229:869-71.

55. Mathison JC, Wolfson E, Ulevitch RJ. Participation of tumor necrosis factor in the mediation of gram negative bacterial lipopolysaccharide-induced injury in rabbits. $\mathrm{J}$ Clin Invest 1988;81:1925-37.

56. Neta R, Plocinski JM, Parenes S, Benjamin W, Chizzonite $\mathrm{R}$, Pilcher $\mathrm{M}$. In vivo modulation with anti $\mathrm{IL}-1$ receptor (p80) antibody 35F5 of the response to IL-1. Blood 1990;76:57-62.

57. Dinarello CA, Rosenwasser LJ, Wolff SM. Demonstration of a circulating suppressor factor of thymocyte proliferation during endotoxin fever in humans. J Immunol 1981;127:2517-9.

58. Liao Z, Grimshaw RS, Rosenstreich DL. Identification of a specific interleukin-1 inhibitor in the urine of febrile patients. J Exp Med 1984;159:125-36.

59. Shaldon S, Koch KM, Bingel M, Granolleras C, Deschodt G, Dinarello CA. Modulation of plasma interleukin-1 and its circulating protein inhibitor (CPI) by hemodialysis and 
hemofiltration. Kidney Int 1987;31:245. (Abst)

60. Arend WP, Joslin FG, Thompson RC, Hannum CH. An IL-1 inhibitor from human monocytes. Production and characterization of biologic properties. J Immunol 1989; 143:1851-8.

61. Seckinger P, Dayer JM. Interleukin-1 inhibitors. Ann Inst Pasteur/Immunol 1987; 138:461-516.

62. Barak V, Treves AJ, Yanai P, et al. Interleukin-1 inhibitory activity secreted by a human myelomonocytic cell line (M20). Eur J Immunol 1986; 16: 1449-52.

63. Isono N, Kumagai K. Production of interleukin-1 inhibitors by the murine macrophage cell line P388D which produces interleukin-1. Microbiol Immunol 1989;33:43-57.

64. Seckinger P, Lowenthal JW, Williamson K, Dayer JM, MacDonald HR. A urine inhibitor of interleukin-1 activity that blocks ligand binding. J Immunol 1987;139:1546-9.

65. Mazzei GJ, Seckinger P, Dayer JM, Shaw AR. Purification and characterization of a $26-\mathrm{kDa}$ competitive inhibitor of interleukin 1. Eur J Immunol 1990;20:683-9.

66. Dayer MMD, Wollheim CB, Seckinger P, Dayer JM. A natural interleukin 1 (IL-1) inhibitor counteracts the inhibitory effect of IL-1 on insulin production in cultured rat pancreatic islets. J Autoimmun 1989;2:163-71.

67. Balavoine JF, Williamson K, Seckinger P, Cruchaud A, Dayer JM. Prostaglandin E2 and collagenase production by fibroblasts and synovial cells is regulated by urine-derived human interleukin 1 and inhibitor(s). $\mathrm{J}$ Clin Invest 1986;78:1120-4.

68. Engelmann H, Aderka D, Rubinstein M, Rotman D, Wallach D. A tumor necrosis factor-binding protein purified to homogeneity from human urine protects cells from tumor necrosis factor toxicity. J Biol Chem 1989;264: 11974-80.

69. Hannum CH, Wilcox CJ, Arend WP, et al. Interleukin-1 receptor antagonist activity of a human interleukin-1 inhibitor. Nature 1990;343:336-40.

70. Eisenberg SP, Evans RJ, Arend WP, et al. Primary structure and functional expression from complementary DNA of a human interleukin-1 receptor antagonist. Nature (Lond) 1990;343:341-6.

71. Carter DB, Deibel MRJ, Dunn CJ, et al. Purification, cloning, expression and biological characterization of an interleukin-1 receptor antagonist protein. Nature 1990;344:633-8.

72. Dayoff MO, Barker WC, Hunt LT. Establishing homologies in protein sequences. Meth Enzymol 1983:91:524-45.

73. Granowitz EV, Mancilla BD, Clark BD, Dinarello CA. The IL-1 receptor antagonist blocks IL- 1 binding to the IL-1RtII on human neutrophils and B-cells. J Biol Chem $1991 ; 266 ; 14147-50$.

74. Rambaldi A, Torcia M, Bettoni S, et al. Modulation of cell proliferation and cytokine production in acute myeloblastic leukemia by interleukin-1 receptor antagonist and lack of its expression by leukemic cells. Blood 1990;76:114a.

75. Ohlsson K, Bjork P, Bergenfeldt M, Hageman R, Thompson RC. Interleukin-1 receptor antagonist reduces mortality from endotoxin shock. Nature 1990;348:550-2.

76. Wakabayashi G, Gelfand JA, Burke JF, Thompson RC, Dinarello CA. A specific receptor antagonist for interleukin-1 prevents $E$ coli-induced shock. FASEB J 1991;5:338-43.

77. Mancilla J, Garcia P, Dinarello CA. Either interleukin-1 or the interleukin-1 receptor antagonist prevent lethal sepsis in newbom rats. Cytokine 1991;3:502. (Abst)

78. Cominelli F, Nast CC, Clark BD, et al. Interleukin-1 gene expression, synthesis and effect of specific IL-1 receptor blockade in rabbit immune complex colitis. J Clin Invest 1990;86:972-80.

79. Cominelli F, Llerena F, Clark BD, Nast CC, Thompson $\mathrm{RC}$, Dinarello CA. In vivo anti-inflammatory properties of recombinant interleukin-1 receptor antagonist (IL-1ra). Lymph Res 1990;9:597. (Abst)

80. Bagby GCJ, Dinarello CA, Neerhout RC, Ridgway D, McCall E. Interleukin 1-dependent paracrine granulopoiesis in chronic granulocytic leukemia of the juvenile type. J Clin Invest 1988;82:1430-6.

81. Cozzolino F, Rubartelli A, Aldinucci D, et al. Interleukin 1 as an autocrine growth factor for acute myeloid leukemia cells. Proc Natl Acad Sci USA 1989;86:2369-73.

82. Arend WP, Welgus HG, Thompson RC, Eisenberg SP. Biological properties of recombinant human monocytederived interleukin-1 receptor antagonist. J Clin Invest 1990;85: 1694-7.

83. Granowitz E, Callahan M, Dinarello CA IL-1 induces ILl. V. The IL- 1 receptor antagonist blocks IL-1 induced IL-1, TNF and IL-6 from purified monocytes. Cytokine 1992;79:2364-9.

84. Ramilo O, Saez-Llorens X, Mertsola J, et al. Tumor necrosis factor $\alpha /$ cachectin and interleukin- $1 \beta$ initiate menigeal inflammation. J Exp Med 1990;172:497-507.

85. Opp MR, Krueger JM. Human interleukin-1 receptor antagonist (ILlra) blocks ILl-induced fever and non-rapideye-movement sleep (NREMS) in rabbits. Am J Physiol 1991;260:R453-7.

86. Ikejima T, Zhang XX, Wen HD, Dinarello CA. Blockade of interleukin-1 and endotoxin-induced fever by the IL1 receptor antagonist in rabbits. Clin Res 1991;39:462. (Abst)

87. Novick D, Engelmann H, Wallach D, Rubinstein M. Soluble cytokine receptors are present in normal human urine. J Exp Med 1989; 170:1409-14.

88. Fanslow WC, Sims JE, Sassenfeld H, et al. Regulation of alloreactivity in vivo by a soluble form of the interleukin-1 receptor. Science 1990;248:739-42.

89. Giri J, Newton RC, Horuk R. Identification of soluble interleukin-1 binding protein in cell-free supernatants. J Biol Chem 1990;265:17416-9. 


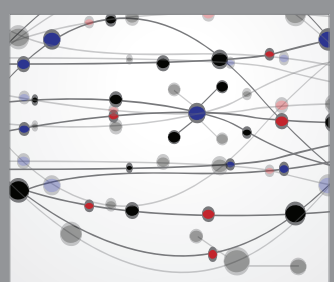

The Scientific World Journal
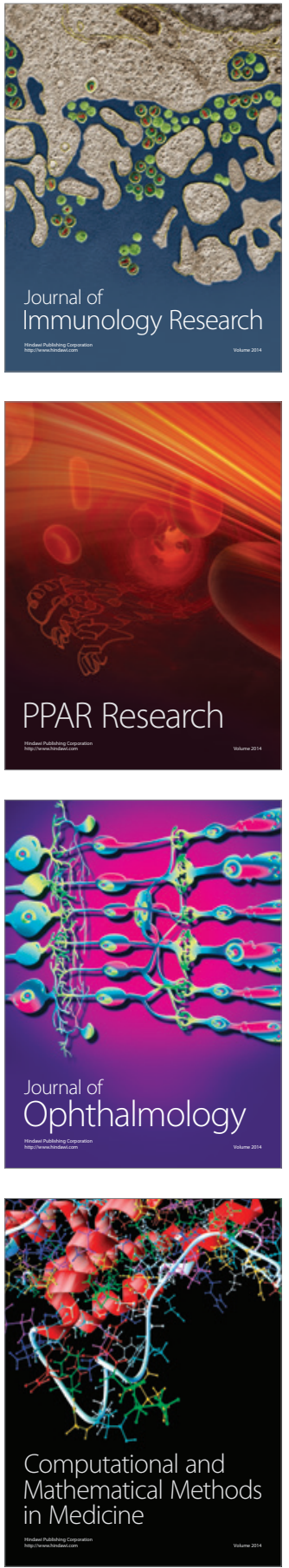

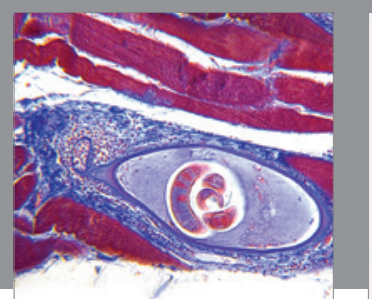

Gastroenterology Research and Practice

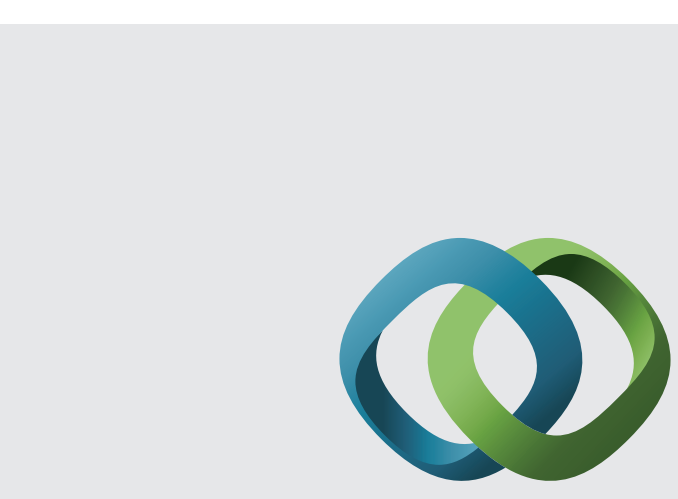

\section{Hindawi}

Submit your manuscripts at

http://www.hindawi.com
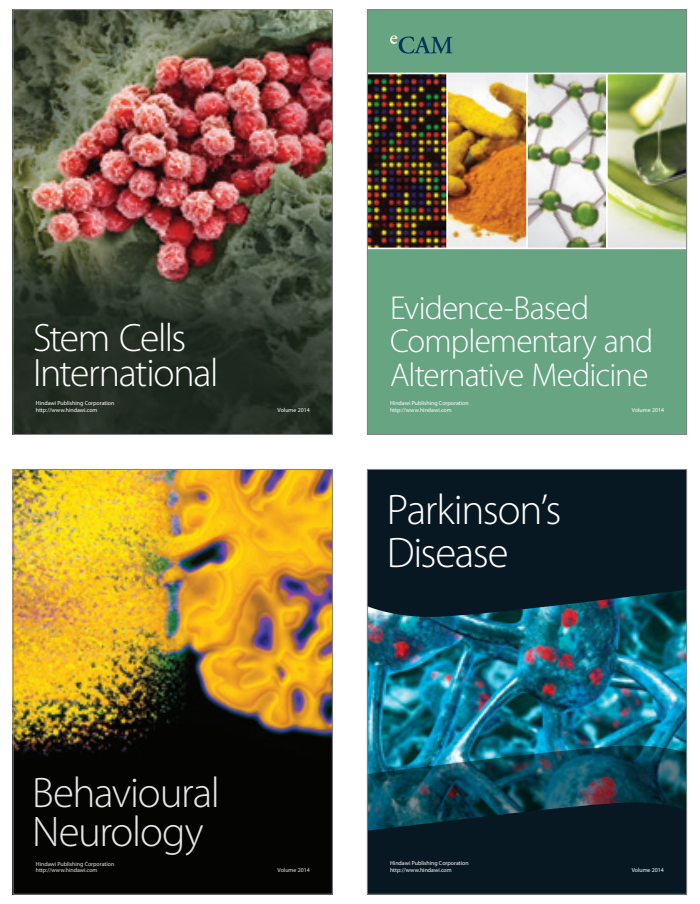
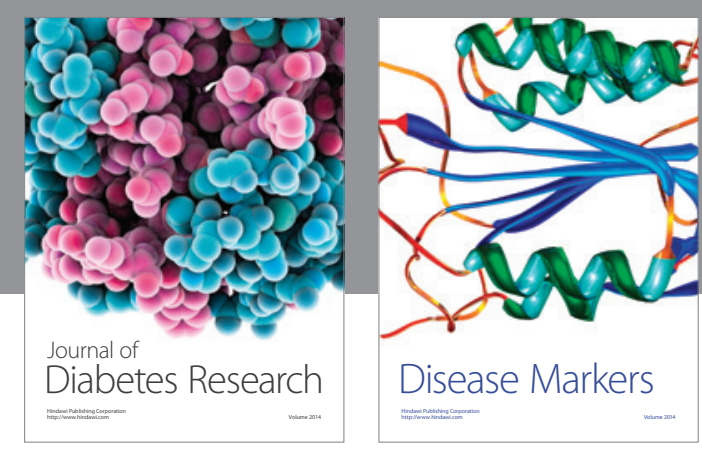

Disease Markers
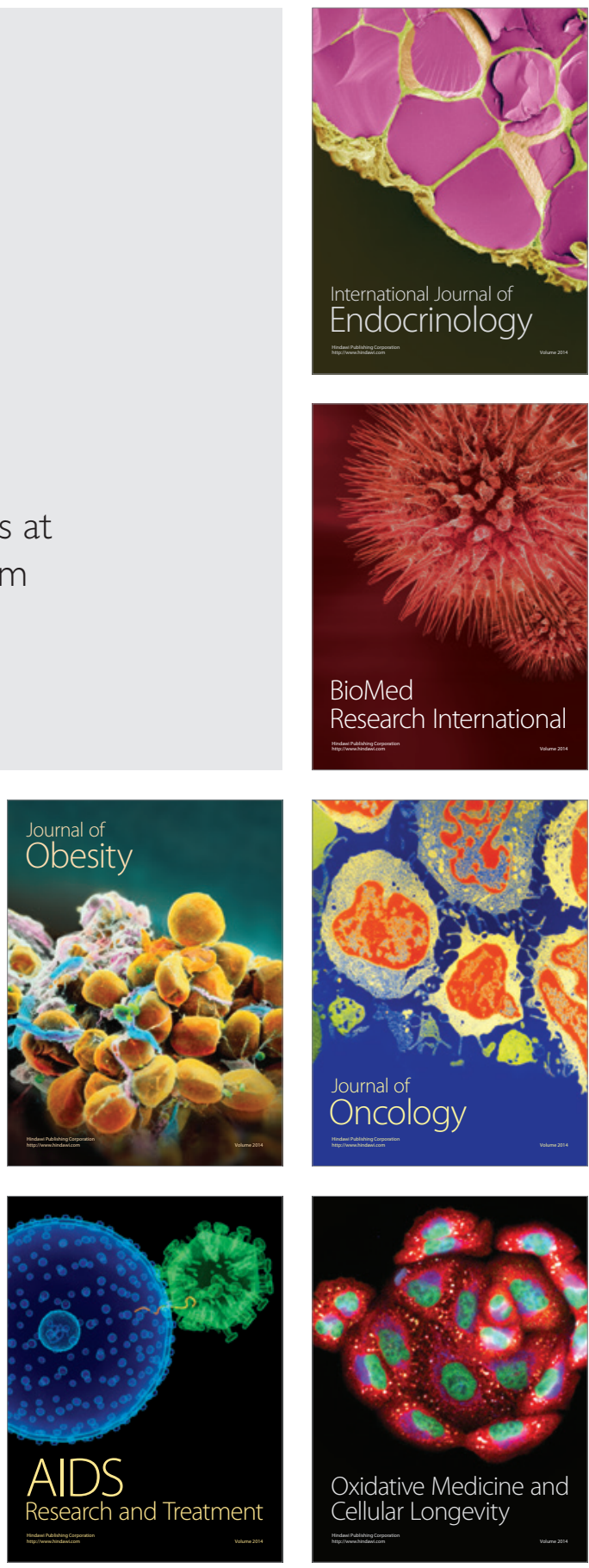